\title{
Pemetaan Daya Saing Internal Universitas Lancang Kuning
}

\author{
JUNAIDI $^{1}$, AFRED SUCI $^{2}$ \\ Universitas Lancang Kuning \\ Jln. Yos Sudarso Km 08 Rumbai Telp. (0761) 52581 Fax. (0761) 52581 \\ E-mail : afredsuci@unilak.ac.id
}

\begin{abstract}
Competitiveness has become a common challenge to many universities in the current era of higher education industrialization. University of Lancang Kuning, as a player in the industry and at the same time is one of the biggest university in Riau Province, clearly must conduct sustainability self evaluation. This study held in scope of 9 faculty. The study aims to analyze the internal competitiveness strength of University of Lancang Kuning. Method of Boston Consulting Group (BCG) conducted to determine the internal market share and proposition of competitive strategy. Analysis measurement is limited to financial secondary data of each faculty and study program. Study reveals that Faculty of Computer Science, Faculty of Economic and Faculty of Law have the highest competitive power based on income ability perspective. These three faculties have high relative market share and high income growth rate. However, in the perspective of reserve fund generating, Faculty of Law and Faculty of Cultural Science become the highest. Meanwhile, in the aspect of financial management balance, Faculty of Agriculture and Faculty of Forestry become the most effective and efficient among other faculties in University of Lancang Kuning
\end{abstract}

Keywords: Competitiveness; Market Share; Higher Education

Salah satu masalah pendidikan tinggi di Indonesia adalah daya saing (Aprilia \& Susilo, 2016). Unilak juga menghadapi kendala yang sama, namun demikian persaingan tersebut merupakan proses yang normal meskipun ada beberapa kejadian yang dirasakan kurang sehat (Hayati \& Satori, 2015). Persaingan muncul akibat dampak dari industrialisasi pendidikan tinggi, sehingga banyak institusi pendidikan tinggi bermunculan secara merata di berbagai daerah (Tobari, 2015; Assauri, 2012), dan bahkan persaingannya tidak lagi dalam skala lokal, namun sudah nasional dan global (Suci, 2017). Konsekuensinya, industri pendidikan tinggi dituntut untuk mampu bersaing agar dapat tumbuh dan berkembang karena kekuatan tawar pengguna jasa pendidikan tinggi mengalami peningkatan dan perubahan (Anggrianto, et al, 2013). Hal ini membuat kondisi perguruan tinggi mengalami dinamika yang cukup berat di era globalisasi saat ini (Rosalin, 2010).

Unilak sebagai salah satu perguruan tinggi swasta terbesar di Provinsi Riau juga harus melakukan evaluasi berkelanjutan, karena mengelola perguruan tinggi sama dengan mengelola bisnis atau perusahaan (Sarjono \& Kuncoro, 2013; Tobari, 2015). Evaluasi diri menjadi bentuk perwujudan akuntabilitas perguruan tinggi yang lazim disebut sebagai EPSBED (Evaluasi Program Studi Berbasis Evaluasi Diri), yang bertujuan untuk menginstropeksi kelayakan pelaksanaan program studi (Sukrisno, 2011). Kelalaian mengevaluasi diri secara berkesinambungan dapat berakibat fatal. Banyak perguruan tinggi swasta gulung tikar atau menutup program studinya karena kalah bersaing, tetapi banyak juga yang tidak menyadari kelemahannya sehingga tetap mengoperasionalkan program studi tertentu meskipun secara ekonomis sudah menjadi parasit bagi universitas induknya (Tobari, 2015). Kondisi ini sebagai dampak adanya pemikiran status quo di kalangan pimpinan perguruan tinggi yang acuh pada orientasi pasar dan lalai pada permasalahan yang terjadi (Hayati \& Satori, 2015) sehingga enggan melakukan upaya evaluasi diri secara berkelanjutan. Unilak wajib untuk terus melakukan 
analisis situasi (Rosalin, 2010), mengevaluasi posisi bersaingnya (Tobari, 2015) dan daya tarik pasarnya (Assauri, 2012). Hal ini perlu dilakukan untuk mengetahui keunggulan bersaing Unilak, termasuk diantaranya adalah mengembangkan program-program unggulan dalam rangka menghadapi persaingan (Suroto, et al, 2016).

Sebagai langkah awal, analisis daya saing internal bisa dilakukan dengan membatasi pada aspek kemampuan finansial. Pendekatan pada perspektif keuangan dilakukan karena bisa dilakukan baik terhadap organisasi laba maupun nirlaba (David, 2009). Selain itu, kondisi keuangan yang sehat adalah salah satu indikator kinerja institusi (Hayati \& Satori, 2015). Faktor keuangan sekaligus menjadi elemen daya saing yang utama (Hayati \& Satori, 2015) dan bentuk pertanggung jawaban terhadap stakeholders (Hermawan \& Widodo, 2008), dan pada kenyataannya permasalahan utama di banyak perguruan tinggi adalah masalah pengelolaan keuangan (Tobari, 2015), sehingga berdampak pada lemahnya kepuasan terhadap sarana dan prasarana (Tobari, 2015), akses literatur berkualitas (Davis \& Walter, 2011) dan lemahnya pendanaan operasional (Aprilia \& susilo, 2016). Pendekatan keuangan pada penelitian dilakukan secara sederhana hanya pada aspek pemasukan dan pengeluaran, karena memang pada umumnya sistem laporan keuangan perguruan tinggi masih banyak dilakukan dengan metode tersebut (Hermawan \& Widodo, 2008).

Dalam ruang lingkup Universitas Lancang Kuning, kajian sejenis ini belum pernah dilakukan sebelumnya, sehingga cukup menyulitkan bagi jajaran pimpinan untuk mengambil kebijakan strategis yang tepat dalam rangka meningkatkan posisi persaingannya. Sehingga dengan demikian maka urjensi penelitian ini adalah dalam rangka pengambilan keputusan strategis yang bisa dilakukan oleh manajemen Unilak dalam menyikapi persaingan. Hasil evaluasi ini bisa menjadi dasar pilihan keputusan strategis (Assauri, 2012) yang bisa dilakukan oleh pimpinan Unilak apakah nantinya akan ditempuh strategi integratif, intensifikasi, diversifikasi atau bahkan penciutan (David, 2009) terhadap sejumlah fakultas tertentu. Penelitian ini dengan demikian dilakukan dengan tujuan untuk mengetahui bagaimana posisi pangsa pasar internal fakultas di lingkungan Unilak.

Perguruan tinggi harus mampu menunjukkan daya saing, yaitu dinamis dalam menghadapi perubahan lingkungan (Rosalin, 2010) dengan cara melakukan analisis situasi internal maupun eksternalnya (Anggrianto, et al, 2013). Daya saing itu sendiri adalah proses dinamis yang meliputi sumber keunggulan posisi dan prestasi akhir suatu investasi laba (Hayati \& Satori, 2015). Keberhasilan organisasi, termasuk perguruan tinggi, bergantung pada keunggulan bersaingnya, sehingga perlu untuk selalu mengevaluasi posisi bersaing (Tobari, 2015) dan daya tarik pasarnya (Assauri, 2012).

Keunggulan bersaing itu sendiri merupakan keunggulan relatif suatu organisasi yang dapat mengungguli pesaingnya (Assauri, 2012). Salah satu indikasi perguruan tinggi yang berdaya saing adalah kemampuan dalam memperkokoh posisi pasarnya (Hayati \& Satori, 2015). Asumsi yang mendasari tercipta dan bertahannya keunggulan kompetitif organisasi adalah kemampuan mengkonfigurasi sumberdaya dengan peluang dan perubahan lingkungan yang terjadi (Breznik \& Lahovnik, 2016).

\begin{tabular}{llr}
\multicolumn{2}{c}{ Diantara perubahan dalam } \\
pendidikan tinggi adalah & fase \\
industrialisasi perguruan tinggi & (Suci, \\
2016; Rosalin, 2010; Tobari, 2015).
\end{tabular}
Sebagai sebuah industri maka perguruan tinggi tak ubahnya sebagai sebuah perusahaan (Sarjono \& Kuncoro, 2013), dan dari perspektif industrialis, perguruan tinggi dianggap sebagai perusahaan yang memproduksi dan menjual produk berupa jasa pendidikan tinggi yang harus 
memiliki keunggulan posisional yang dinyatakan dalam bentuk kinerja (Tobari, 2015). Daya saing perguruan tinggi dipengaruhi oleh faktor internal dan eksternal. Faktor internal terdiri dari: sumberdaya organisasi, pemasaran atau orientasi pasar, sumberdaya manusia, orientasi pembelajaran, fasilitas fisik, sumberdaya finansial, penelitian dan pengembangan. Diantara faktor keunggulan internal adalah program studi yang ada wajib menyediakan fasilitas yang mampu memuaskan pengguna jasanya (Sukandi, 2010).

Sedangkan faktor eksternal terdiri dari aspek persaingan, ancaman dari pesaing, ancaman pendatang baru, kekuatan tawar mahasiswa dan kekuatan tawar dari pengguna (Hayati \& Satori, 2015). Dalam hal ini Wang (2014) menyatakan bahwa dalam konsep market-based view faktorfaktor industri dan orientasi pasar eksternal merupakan kunci utama keberhasilan kinerja organisasi. Sumber nilainya melekat dalam situasi persaingan yang membentuk posisi strategis pada produk akhirnya. Sehingga keunggulan kompetitif diraih ketika organisasi mengembangkan atau melakukan upaya yang memungkinkannya memenangkan persaingan (Wang, 2014).

Perguruan tinggi sendiri mayoritas menerapkan struktur divisional yang otonom dan terdesentralisasi (Davis, 2009) dalam bentuk fakultas dan prodi-prodi yang ada didalamnya. Sehingga dalam hal ini bisa diekuivalenkan bahwa universitas merupakan korporat yang menaungi sejumlah unit atau divisi, dimana Assauri (2012) menyatakan bahwa korporat harus memutuskan strategi korporasi untuk posisi bersaing dan pengalokasian sumberdaya untuk divisi-divisi tersebut. Dengan demikian, perguruan tinggi harus melakukan analisis situasi daya saing (Rosalin, 2010), posisi pangsa pasar persaingan (Tobari, 2015) dan daya tarik berupa potensi pasarnya (Assauri, 2012) untuk menghadapi persaingan di industri pendidikan tinggi.

\section{METODE}

Data-data pada penelitian ini bersifat sekunder yaitu berupa data pendapatan, pengeluaran dan dana cadangan fakultas yang ada di lingkungan Unilak dalam 3 semester terakhir. Variabel penelitian ini adalah daya saing yang merupakan suatu proses dinamis meliputi sumber-sumber keunggulan posisi dan prestasi akhir suatu investasi laba (Hayati \& Satori, 2015). Indikator penilaian daya saing berdasarkan analisis posisi pangsa pasar (Tobari, 2015) berdasarkan aspek pendapatan, pengeluaran dan kemampuan setiap fakultas dalam menghasilkan dana cadangan setiap periode/semester.

Jenis penelitian adalah penelitian deskriptif yang pada dasarnya ditujukan untuk memaparkan situasi atau peristiwa (Rakhmat, 2009:24-25). Alat analisis yang digunakan untuk menentukan daya saing pangsa pasar internal fakultas/prodi di lingkungan Unilak dilakukan dengan menggunakan analisis Boston Consulting Group (BCG).

\section{HASIL}

Pengujian pada analisis deskriptif dilakukan dengan menggunakan statistika deskriptif dalam rangka mengetahui dan menganalisis kemampuan masing-masing fakultas yang ada di Universitas Lancang Kuning dalam menghasilkan pendapatan, pengeluaran dan kemampuan membentuk dana cadangan. Secara agregat, UNILAK secara rata-rata mampu memperoleh pencapaian positif dalam aspek pengelolaan pendapatan, pengeluaran dan kemampuan pembentukan dana cadangan dari seluruh fakultas yang ada. Kemampuan pembentukan dana cadangan rata-rata diseluruh fakultas mampu menembus $4,51 \%$ dalam tiga semester terakhir. Adapun kecepatan generate pendapatan mencapai $0,95 \%$ persemester, sementara laju pengeluaran bisa ditekan menjadi $0,70 \%$ persemester. Maknanya ada efisiensi yang cukup baik karena laju kecepatan pengeluaran masih dibawah kecepatan pendapatan. 
Tabel 1. Performa Keuangan Fakultas di Lingkungan Universitas
Lancang Kuning Periode 2015 Hingga 2018

\begin{tabular}{|c|c|c|c|c|c|c|c|c|c|c|c|}
\hline \multirow{2}{*}{ 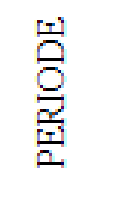 } & \multirow[t]{2}{*}{$\stackrel{\leftrightarrows}{\leftrightarrows}$} & 胥 & 됟 & $\stackrel{\Xi}{\leftrightarrows}$ & $\frac{8}{8}$ & 言 & 臭 & 宝 & 壱 & $\frac{\sqrt{4}}{\frac{8}{7}}$ & 鄫 \\
\hline & & $\%$ & $\%$ & $\%$ & $\%$ & $\%$ & $\%$ & $\%$ & $\%$ & $\%$ & $\%$ \\
\hline $\begin{array}{l}\text { Ganjil } \\
2015 / \\
2016\end{array}$ & $\begin{array}{l}\text { Rasio dana } \\
\text { cadangan }\end{array}$ & 19.83 & 0.36 & 0.62 & 3.57 & 0.57 & 1.26 & 0.00 & 0.00 & 0.28 & 3.98 \\
\hline \multirow{3}{*}{$\begin{array}{l}\text { Genap } \\
2016 / \\
2017\end{array}$} & $\begin{array}{l}\text { Rasio dana } \\
\text { cadangan }\end{array}$ & 12.73 & 0.55 & 0.09 & 0.22 & 2.43 & 20.08 & 0.01 & 3.81 & 0.78 & 5.05 \\
\hline & $\Delta$ pendapatan & 19.41 & 3.36 & -5.73 & -3.66 & 144.2 & 39.37 & 43.18 & 14.24 & 3.47 & 3.56 \\
\hline & $\Delta$ pengeluaran & 25.97 & 3.18 & -5.17 & -0.18 & 148.8 & 25.09 & 43.18 & 10.85 & 2.98 & 2.47 \\
\hline \multirow{3}{*}{$\begin{array}{l}\text { Ganjil } \\
2017 / \\
2018\end{array}$} & $\begin{array}{l}\text { Rasio dana } \\
\text { cadangan }\end{array}$ & 12.90 & 0.25 & 1.84 & 1.89 & 0.07 & 14.06 & 0.74 & 0.00 & 2.01 & 4.50 \\
\hline & $\Delta$ pendapatan & 14.67 & 10.71 & 13.87 & 1.08 & 1.95 & -1.47 & -0.64 & 36.07 & 30.49 & -1.66 \\
\hline & $\Delta$ pengeluaran & 14.89 & 10.38 & 15.90 & -0.61 & 4.27 & 5.64 & -1.38 & 38.50 & 29.61 & -1.08 \\
\hline \multirow{3}{*}{$\begin{array}{l}\text { Rata- } \\
\text { rata }\end{array}$} & $\begin{array}{l}\text { Rasio dana } \\
\text { cadangan }\end{array}$ & 15.15 & 0.38 & 0.85 & 1.89 & 1.02 & 11.80 & 0.25 & 1.27 & 1.03 & 4.51 \\
\hline & $\Delta$ pendapatan & 2.37 & -3.67 & -9.80 & -1.29 & 71.10 & 18.95 & 21.27 & 25.16 & 16.98 & 0.95 \\
\hline & $\Delta$ pengeluaran & 5.54 & -3.60 & 10.54 & -0.39 & 72.27 & 15.37 & 20.90 & 24.67 & 16.30 & 0.70 \\
\hline
\end{tabular}

Sumber: data olahan, 2018

\section{Fakultas Hukum}

Dari sisi kemampuan mengumpulkan pendapatan, Fakultas Hukum (FH) menempati urutan ketiga setelah Fakultas Ilmu Komputer (FKOM) dan Fakultas Ekonomi (FE). Pada periode semester Genap TA. 2016/2017, FH berhasil membukukan kenaikan pertumbuhan pendapatan ketiga terbesar $(19,41 \%)$ setelah Fakultas Teknik $(43,18 \%)$ dan Fakultas Ilmu Budaya (39,37\%). Jika dibandingkan dengan aspek pengeluaran terlihat bahwa pada semester yang sama, FH justru mengalami kenaikan pengeluaran yang signifikan diatas pertumbuhan pendapatan yaitu $25,97 \%$. Artinya, kecepatan pengeluaran jauh lebih besar dibandingkan kecepatan pertumbuhan pendapatannya. Namun pada semester Ganjil TA. 2017/2018, kemampuan menggenerate pendapatan pada $\mathrm{FH}$ menurun drastis sebesar $-14,67 \%$ - dimana penurunan ini merupakan yang tertinggi dibandingkan fakultas lainnya.
Adapun kecepatan pertumbuhan pengeluaran juga mengalami penurunan sebesar $-14,89 \%$. Maknanya, pada semester ini, FH sudah berhasil menyeimbangkan laju pertumbuhan pengeluarannya yang disesuaikan dengan kemampuannya dalam menumbuhkan pendapatannya.

Rata-rata pertumbuhan pendapatan di $\mathrm{FH}$ adalah $2,37 \%$ persemester, sedangkan pertumbuhan pengeluaran sebesar $5,54 \%$ persemester. Maknanya, FH mengalami pertumbuhan pengeluaran yang lebih cepat dibandingkan dengan kemampuannya dalam memperoleh pendapatan. Dibandingkan dengan fakultas lainnya, $\mathrm{FH}$ menjadi fakultas dengan kemampuan pembentukan dana cadangan yang terbesar rata-rata setiap semesternya yaitu $15,15 \%$. Namun dalam skala semesteran, hanya pada Ganjil TA. 2015/2016 saja FH mengungguli fakultas lainnya, karena pada dua semester berikutnya, posisi ini dipegang oleh FIB. 


\section{Fakultas Ekonomi}

Dari sisi kemampuan mengumpulkan pendapatan, Fakultas Ekonomi (FE) menempati urutan kedua setelah Fakultas Ilmu Komputer (FKOM). Pada periode semester Genap TA. 2016/2017, FH berhasil membukukan kenaikan pertumbuhan pendapatan sebesar 3,36\%. Namun angka ini masih jauh dibawah kemampuan Fakultas Teknik $(43,18 \%)$ dan Fakultas Ilmu Budaya (39,37\%). Jika dibandingkan dengan aspek pengeluaran terlihat bahwa pada semester yang sama, FE cukup berhasil mengelola kecepatan pertumbuhan pengeluarannya pada rentang $3,18 \%$. Namun pada semester Ganjil TA. 2017/2018, kemampuan menggenerate pendapatan pada FE menurun drastis sebesar $-10,71 \%$ - dimana penurunan ini merupakan yang kedua tertinggi dibandingkan fakultas lainnya. Adapun kecepatan dalam pertumbuhan pengeluaran juga mengalami penurunan sebesar $-10,38 \%$. Maknanya, pada semester ini, FE juga cukup mampu menyeimbangkan laju pertumbuhan pengeluarannya yang disesuaikan penurunan yang terjadi pada pertumbuhan pendapatannya.

Rata-rata pertumbuhan pendapatan di FE adalah $-3,67 \%$ persemester, sedangkan pertumbuhan pengeluaran sebesar $-3,60 \%$ persemester. Maknanya, FE mengalami pertumbuhan pengeluaran yang sedikit lebih lambat dibandingkan dengan kemampuannya dalam memperoleh pendapatan. Dibandingkan dengan fakultas lainnya, FE menjadi fakultas dengan kemampuan pembentukan dana cadangan yang kedua terendah dimana rata-rata setiap semesternya hanya tumbuh $0,38 \%$.

\section{Fakultas Ilmu Administrasi}

Dari sisi kemampuan mengumpulkan pendapatan, Fakultas Ilmu Administrasi (FIA) menempati urutan kelima setelah FKOM, FE, FH dan FIA. Pada periode semester Genap TA. 2016/2017, FIA membukukan penurunan pertumbuhan pendapatan sebesar $-5,75 \%$. Angka tersebut merupakan terendah kedua setelah FKIP ($144,15 \%)$. Jika dibandingkan dengan aspek pengeluaran terlihat bahwa pada semester yang sama, FIA cukup berhasil mengelola kecepatan pertumbuhan pengeluarannya pada rentang $-5,17 \%$ sehingga tidak terjadi persentase defisit yang lebar dengan kemampuannya dalam menggenerate pendapatan.

Pada semester Ganjil TA. 2017/2018, kemampuan menggenerate pendapatan pada FIA kembali menurun signifikan sebesar $-13,87 \%$ - dimana penurunan ini merupakan yang kedua tertinggi dibandingkan fakultas lainnya. Adapun kecepatan dalam pertumbuhan pengeluaran juga mengalami penurunan sebesar $-15,90 \%$. Maknanya, pada semester ini, FIA kurang berhasil menyeimbangkan laju pertumbuhan pengeluarannya karena lebih cepat daripada penurunan yang terjadi pada pertumbuhan pendapatannya.

Rata-rata pertumbuhan pendapatan di FIA adalah $-9,80 \%$ persemester atau yang terendah kedua setelah FKIP (71,10\%), sedangkan pertumbuhan pengeluaran sebesar $-10,54 \%$ persemester atau yang terendah kedua setelah FKIP (72,27\%). Maknanya, FIA mengalami pertumbuhan pengeluaran yang sedikit lebih cepat dibandingkan dengan kemampuannya dalam memperoleh pendapatan. Dibandingkan dengan fakultas lainnya, FIA menjadi fakultas dengan kemampuan pembentukan dana cadangan yang ketiga terendah dimana rata-rata setiap semesternya hanya tumbuh $0,85 \%$.

\section{Fakultas Ilmu Komputer}

Dari sisi kemampuan mengumpulkan pendapatan, Fakultas Ilmu Komputer (FKOM) menempati urutan pertama dari seluruh fakultas. Meskipun dalam hal pengumpulan mahasiswa, FKOM hanya menempati urutan ketiga, namun dari sisi nominal pendapatan merupakan yang tertinggi. Hal ini dikarenakan adanya beberapa kegiatan yang memang menyerap banyak pemasukan dana dari mahasiswa (diluar SPP dan iuran wajib lain), seperti kegiatan field trip yang dilakukan setiap semester, baik untuk melakukan perjalanan 
kedalam maupun keluar negeri; dan kegiatan SKPI (Surat Keterangan Pendamping Ijazah) yang juga menyerap dana mahasiswa yang cukup besar untuk memperoleh sertifikasi kompetensi tertentu.

Pada periode semester Genap TA. 2016/2017, FKOM membukukan penurunan pertumbuhan pendapatan sebesar $-3,66 \%$. Angka tersebut merupakan terendah ketiga setelah FKIP $(-144,15 \%)$ dan FIA $(-5,73 \%)$. Jika dibandingkan dengan aspek pengeluaran terlihat bahwa pada semester yang sama, FKOM berhasil menekan kecepatan pertumbuhan pengeluarannya pada rentang $0,18 \%$ sehingga tidak terjadi persentase defisit yang lebar dengan kemampuannya dalam menggenerate pendapatan.

Pada semester Ganjil TA. 2017/2018, kemampuan menggenerate pendapatan pada FKOM mampu rebound positif sebesar $1,08 \%$. Adapun kecepatan dalam pertumbuhan pengeluaran justru mampu ditekan sebesar -0,61\%. Maknanya, pada semester ini, FKOM berhasil surplus sehingga pembentukan dana cadangan tetap bisa positif sebesar $1,89 \%$ (ketiga tertinggi) meskipun pendapatannya mengalami penurunan.

Rata-rata pertumbuhan pendapatan di FKOM adalah $-1,29 \%$ persemester atau yang terendah keempat, sedangkan kecepatan pertumbuhan pengeluaran sebesar -0,39\% persemester atau yang terendah keempat. Namun kemampuan membentuk dana cadangan tetap mampu positif di kisaran $1,89 \%$. Maknanya, FKOM mampu menekan pertumbuhan pengeluaran yang lebih rendah dibandingkan dengan kemampuannya dalam memperoleh pendapatan. Dibandingkan dengan fakultas lainnya, FKOM menjadi fakultas dengan kemampuan pembentukan dana cadangan yang ketiga tertinggi dimana rata-rata setiap semesternya tumbuh $1,89 \%$.

\section{Fakultas Keguruan dan Ilmu Pendidikan}

Dari sisi kemampuan mengumpulkan pendapatan, Fakultas Keguruan dan Ilmu Pendidikan (FKIP) menempati urutan keempat setelah FKOM, FE dan FH. Namun pencapaian ini hanya terjadi pada semester
Ganjil TA. 2015/2016 saja, karena pada dua semester terakhir, pencapaian pendapatan FKIP jatuh sangat signifikan hingga lebih dari $100 \%$. Pada periode semester Genap TA. 2016/2017, FKIP membukukan penurunan pertumbuhan pendapatan $144,15 \%$. Angka tersebut merupakan terendah di seluruh fakultas yang ada di Universitas Lancang Kuning. Hal ini sekaligus menunjukkan bahwa pada dasarnya FKIP memiliki idle capacity yang sangat besar karena kapasitas yang tidak terpakainya tidak dapat dimanfaatkan optimal.

Jika dibandingkan dengan aspek pengeluaran terlihat bahwa pada semester yang sama, FKIP justru mengalami kecepatan pertumbuhan pengeluarannya pada rentang $-148,80 \%$ atau lebih besar dari kemampuannya menggenerate pendapatan. Artinya bisa disimpulkan bahwa ada anomali sangat drastis yang terjadi, sehingga kemampuan pendapatan FKIP menjadi sangat lemah, namun di sisi lain justru terjadi inefisiensi pengeluaran yang pertumbuhannya lebih cepat dibandingkan dengan kemampuan pertumbuhan pendapatannya.

$$
\text { Pada semester Ganjil TA. }
$$

2017/2018, kemampuan menggenerate pendapatan pada FKIP mampu sedikit ditingkatkan sebesar $1,95 \%$ - dimana kenaikan ini merupakan yang ketiga tertinggi setelah FHUT dan FAPERTA. Namun kecepatan dalam pertumbuhan pengeluaran mengalami kenaikan sebesar 4,27\%. Maknanya, pada semester ini, FKIP kembali kurang berhasil menyeimbangkan laju pertumbuhan pengeluarannya karena jauh lebih cepat daripada peningkatan yang terjadi pada pertumbuhan pendapatannya.

Rata-rata pertumbuhan pendapatan di FKIP adalah $-71,10 \%$ persemester atau yang terendah dari seluruh fakultas yang ada, sedangkan pertumbuhan pengeluaran sebesar $-72,27 \%$ persemester atau yang terendah dari seluruh fakultas. Maknanya, FKIP mengalami pertumbuhan pengeluaran yang sedikit lebih cepat dibandingkan dengan kemampuannya dalam memperoleh 
pendapatan. Dibandingkan dengan fakultas lainnya, FKIP menjadi fakultas dengan kemampuan pembentukan dana cadangan yang keenam tertinggi dimana rata-rata setiap semesternya hanya tumbuh $1,02 \%$.

\section{Fakultas Ilmu Budaya}

Dari sisi kemampuan mengumpulkan pendapatan, Fakultas Ilmu Budaya (FIB) menempati urutan keempat setelah FKOM, FE dan FH. Pada periode semester Genap TA. 2016/2017, FIB mampu membukukan kenaikan pertumbuhan pendapatan sebesar $39,37 \%$. Angka tersebut merupakan tertinggi kedua setelah FT $(43,18 \%)$. Jika dibandingkan dengan aspek pengeluaran terlihat bahwa pada semester yang sama, FIB berhasil mengelola kecepatan pertumbuhan pengeluarannya pada rentang 25,09\% sehingga FIB mampu surplus dalam rasio pendapatan dan pengeluarannya.

Pada semester Ganjil TA. 2017/2018, kemampuan menggenerate pendapatan pada FIB menurun sebesar $-1,47 \%$ - dimana penurunan ini merupakan yang keempat tertinggi dibandingkan fakultas lainnya. Adapun kecepatan dalam pertumbuhan pengeluaran justru mengalami peningkatan sebesar 5,64\%. Maknanya, pada semester ini, FIB relatif tidak berhasil menyeimbangkan laju pertumbuhan pengeluarannya karena lebih cepat daripada penurunan yang terjadi pada pertumbuhan pendapatannya.

Rata-rata pertumbuhan pendapatan di FIB adalah $18,95 \%$ persemester atau yang tertinggi ketiga setelah FHUT $(25,16 \%)$ dan FT $(21,27 \%)$, sedangkan pertumbuhan pengeluaran sebesar $15,37 \%$ persemester atau yang tertinggi keempat. Maknanya, FIB mengalami pertumbuhan pengeluaran yang relative lebih rendah dalam tiga semester terakhir dibandingkan dengan kemampuannya dalam memperoleh pendapatan. Dibandingkan dengan fakultas lainnya, FIB menjadi fakultas dengan kemampuan pembentukan dana cadangan yang kedua tertinggi dimana rata-rata setiap semesternya mampu tumbuh $11,80 \%$.

\section{Fakultas Teknik}

Dari sisi kemampuan mengumpulkan pendapatan, Fakultas Teknik (FT) menempati urutan keenam setelah FKOM, FE, FH, FIB dan FIA. Pada periode semester Genap TA. 2016/2017, FT membukukan kenaikan pertumbuhan pendapatan 43,18\%. Angka tersebut merupakan yang tertinggi di seluruh fakultas yang ada di Universitas Lancang Kuning. Jika dibandingkan dengan aspek pengeluaran terlihat bahwa pada semester yang sama, FT mengalami kecepatan pertumbuhan pengeluarannya pada rentang $43,18 \%$ atau sama dengan kemampuannya menggenerate pendapatan.

Pada semester Ganjil TA. 2017/2018, kemampuan menggenerate pendapatan pada FT sedikit menurun sebesar $-0,64 \%$. Namun kecepatan dalam pertumbuhan pengeluaran mampu ditekan sebesar $-1,38 \%$. Maknanya, pada semester ini, FT berhasil menyeimbangkan laju pertumbuhan pengeluarannya agar tidak defisit terhadap laju penurunan kemampuan pendapatannya.

Rata-rata pertumbuhan pendapatan di FT adalah $21,27 \%$ persemester atau yang tertinggi kedua setelah FHUT $(25,16 \%)$, sedangkan pertumbuhan pengeluaran sebesar $20,90 \%$ persemester atau yang tertinggi kedua setelah FHUT $(24,67 \%)$. Maknanya, FT mengalami pertumbuhan pengeluaran yang sedikit lebih lambat dibandingkan dengan kemampuannya dalam memperoleh pendapatan. Dapat dikatakan bahwa ada efisiensi yang cukup baik dalam pengelolaan pengeluaran di FT. Namun demikinan, dibandingkan dengan fakultas lainnya, FT menjadi fakultas dengan kemampuan pembentukan dana cadangan yang terendah dimana rata-rata setiap semesternya hanya tumbuh $0,25 \%$.

\section{Fakultas Kehutanan}

Dari sisi kemampuan

mengumpulkan pendapatan, Fakultas Kehutanan (FHUT) adalah yang paling rendah dari seluruh fakultas yang ada, dikarenakan jumlah mahasiswanya juga 
yang paling sedikit. Pada periode semester Genap TA. 2016/2017, FHUT membukukan kenaikan pertumbuhan pendapatan sebesar 14,24\%. Angka tersebut merupakan yang tertinggi keempat setelah FT, FIB dan FH. Jika dibandingkan dengan aspek pengeluaran terlihat bahwa pada semester yang sama, FHUT mengalami kecepatan pertumbuhan pengeluarannya pada rentang $10,85 \%$ atau relatif jauh lebih rendah dibandingkan dengan laju pendapatannya. Hal ini menunjukkan pada semester ini FHUT cukup berhasil mengelola pengeluarannya secara efisien.

Pada semester Ganjil TA. 2017/2018, kemampuan menggenerate pendapatan pada FT meningkat drastis sebesar $36,07 \%$ yang sekaligus menjadi yang tertinggi dibandingkan pencapaian seluruh fakultas di Universitas Lancang Kuning. Ketika fakultas-fakultas besar mengalami penurunan cukup signifikan, FHUT bersama FAPERTA justru berhasil mencatatkan pencapaian positif yang signifikan. Namun demikian kecepatan laju pengeluaran FHUT pada periode ini menjadi $38,50 \%$ yang merupakan tertinggi di Universitas Lancang Kuning. Maknanya, ada sedikit inefisiensi dalam pengelolaan pengeluaran sehingga lajunya menjadi lebih cepat dibandingkan laju pendapatannya.

Rata-rata pertumbuhan pendapatan di FHUT adalah $25,16 \%$ persemester atau yang tertinggi di seluruh Universitas Lancang Kuning, sedangkan pertumbuhan pengeluaran sebesar $24,67 \%$ persemester atau yang tertinggi dari seluruh fakultas yang ada. Maknanya, FHUT mengalami pertumbuhan pengeluaran yang sedikit lebih lambat dibandingkan dengan kemampuannya dalam memperoleh pendapatan. Dapat dikatakan bahwa ada efisiensi yang cukup baik dalam pengelolaan pengeluaran di FHUT dalam tiga semester terakhir. Dibandingkan dengan fakultas lainnya, FHUT menjadi fakultas dengan kemampuan pembentukan dana cadangan yang keempat tertinggi dimana rata-rata setiap semesternya mampu tumbuh $1,27 \%$.

\section{Fakultas Pertanian}

Dari sisi kemampuan mengumpulkan pendapatan, Fakultas Pertanian (FAPERTA) adalah yang terendah ketiga dari seluruh fakultas yang ada di Universitas Lancang Kuning. Pada periode semester Genap TA. 2016/2017, FAPERTA membukukan kenaikan pertumbuhan pendapatan sebesar $3,47 \%$. Angka tersebut merupakan yang tertinggi kelima setelah FT, FIB, FH dan FHUT. Jika dibandingkan dengan aspek pengeluaran terlihat bahwa pada semester yang sama, FAPERTA mengalami kecepatan pertumbuhan pengeluarannya pada rentang $2,98 \%$ atau relatif lebih rendah dibandingkan dengan laju pendapatannya. Hal ini menunjukkan pada semester ini FAPERTA cukup berhasil mengelola pengeluarannya secara efisien.

Pada semester Ganjil TA. 2017/2018, kemampuan menggenerate pendapatan pada FAPERTA meningkat drastis sebesar $30,49 \%$ yang sekaligus menjadi yang tertinggi kedua setelah FHUT. Ketika fakultas-fakultas besar mengalami penurunan cukup signifikan, FAPERTA bersama FHUT justru berhasil mencatatkan pencapaian positif yang signifikan. Dalam hal kecepatan laju pengeluaran FAPERTA pada periode ini menjadi $29,61 \%$ yang merupakan tertinggi kedua setelah FHUT. Meskipun tinggi, namun rasionya masih dibawah laju perubahan pendapatan. Maknanya, ada sedikit inefisiensi dalam pengelolaan pengeluaran yang tubuh organisasi FAPERTA.

Rata-rata pertumbuhan pendapatan di FAPERTA adalah $16,98 \%$ persemester atau yang tertinggi keempat di seluruh Universitas Lancang Kuning, sedangkan pertumbuhan pengeluaran sebesar 16,30\% persemester atau yang tertinggi ketigas dari seluruh fakultas yang ada. Maknanya, FAPERTA mengalami pertumbuhan pengeluaran yang sedikit lebih lambat dibandingkan dengan kemampuannya dalam memperoleh pendapatan. Dapat dikatakan bahwa ada efisiensi yang cukup 
baik dalam pengelolaan pengeluaran di FAPERTA dalam tiga semester terakhir. Dibandingkan dengan fakultas lainnya, FAPERTA menjadi fakultas dengan kemampuan pembentukan dana cadangan yang kelima tertinggi dimana rata-rata setiap semesternya mampu tumbuh $1,03 \%$.

\section{PEMBAHASAN}

Untuk menentukan posisi pangsa pasar masing-masing fakultas di Universitas Lancang Kuning, maka sebelumnya perlu diketahui berapa posisi fakultas pada masingmasing sumbu pangsa pasar relatif $(\mathrm{X})$ dan pangsa pasar relatif yang tinggi, baik FKOM, FE maupun FH juga memiliki tingkat pertumbuhan pendapatan yang tinggi dari sisi nominal.

Oleh karena skor pangsa pasar relatif dan tingkat pertumbuhan pendapatan yang berada pada kategori tinggi, maka sesuai dengan David (2009), ketiga fakultas yaitu FKOM, FE dan FH digolongkan kedalam kategori 'Star' yang merupakan kolom matriks terbaik atau terbesar dari aspek pendapatan, dimana unit yang masuk kedalam kategori ini memiliki

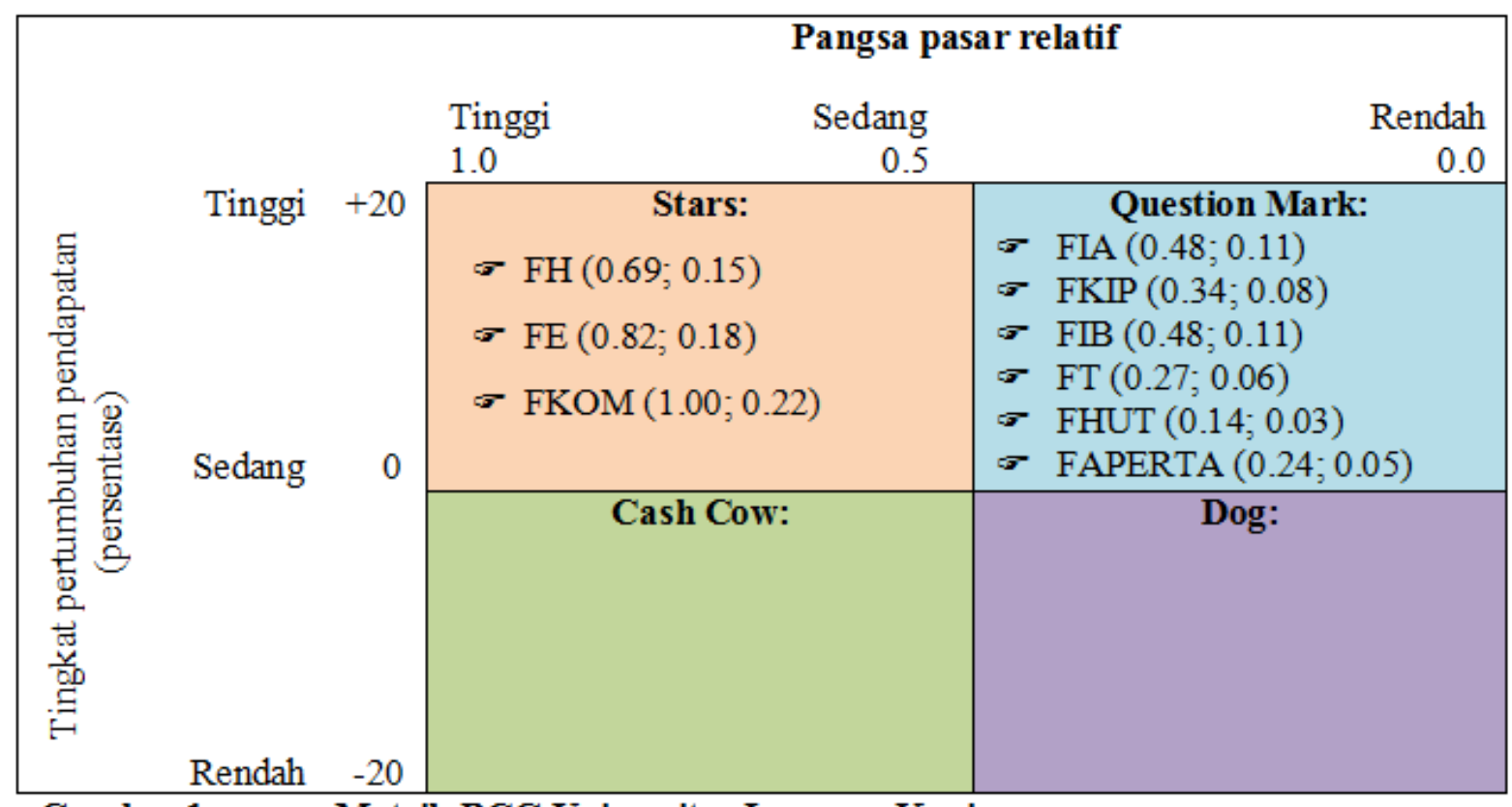

Gambar 1 : Matrik BCG Universitas Lancang Kuning

Sumber Data olahan

tingkat pertumbuhan dari sisi pendapatan fakultas (Y).

\section{Kategori 'Stars'}

Pada kategori ini diartikan bahwa Fakultas Hukum (FH), Fakultas Ekonomi (FE) dan Fakultas Ilmu Komputer (FKOM) memiliki pangsa pasar relatif tinggi, dimana FKOM merupakan pangsa relatif tertinggi dari sisi pendapatan, kemudian diikuti oleh FE dan FH. Pendapatan ketiga fakultas ini mendominasi pendapatan Unilak secara keseluruhan, yang menunjukkan bahwa ketiga fakultas ini merupakan fakultas terbesar dari sisi kontribusi pendapatan maupun jumlah mahasiswanya. Selain keleluasaan yang lebih besar untuk melakukan beragam strategi pengembangan.

David (2009) memberikan sejumlah strategi alternatif pengembangan yang bisa dilakukan oleh unit 'Stars' yakni: dapat melakukan integrasi ke depan maupun ke belakang; melakukan penetrasi pasar; pengembangan pasar, dan; pengembangan produk. Dalam konteks keunggulan bersaing menurut Assauri (2012) maka posisi FKOM, FE dan FH dalam hal ini memiliki daya tarik yang paling kuat, khususnya bagi pendaftar baru yang otomatis akan mendorong terjadinya peningkatan p.ISSN: $2407-800 \mathrm{X} \quad$ e.ISSN: 2541-4356 
pendapatan bagi kampus. Ketiga fakultas ini mendominasi performa Universitas Lancang Kuning, sebagaimana yang dinyatakan Hayati \& Satori (2015) bahwa ciri keunggulan adalah kemampuan memperkokoh posisi pasarnya.

Khususnya oleh Fakultas Hukum yang rata-rata kemampuan pembentukan dana cadangannya paling tinggi, dengan dukungan akreditasi A, semestinya bisa lebih agresif dalam mengembangkan unitnya, dan sebagaimana dinyatakan oleh Suci (2017) bahwa sudah saatnya untuk mengembangkan posisi persaingan tidak lagi dalam konteks lokal namun sudah harus menasional. Demikian pula dengan FE dan FKOM yang bisa mengoptimalkan besarnya pendapatan yang diraihnya dengan mengembangkan sejumlah alternatif strategi yang tersedia.

\section{Kategori 'Question Mark'}

Terdapat 6 fakultas yang masuk dalam kategori ini, yaitu Fakultas Ilmu Administrasi (FIA), Fakultas Keguruan dan Ilmu Pendidikan (FKIP), Fakultas Ilmu Budaya (FIB), Fakultas Teknik (FT), Fakultas Kehutanan (FHUT) dan Fakultas Pertanian (FAPERTA). Keenam fakultas ini memiliki tingkat pertumbuhan pendapatan yang tinggi secara nominal, namun pangsa pasar relatifnya tergolong rendah.

Menurut David (2009), kondisi ini bisa didorong ke arah 'Stars' dengan melakukan investasi atau upaya lain agar unit-unit yang ada didalamnya mampu mengoptimalkan tingkat pertumbuhan pendapatannya yang tinggi untuk memperbesar posisi pangsa pasar relatifnya. Khususnya adalah FIB, yang dari hasil analisis deskriptif menunjukkan kemampuan pembentukan dana cadangan yang baik dibandingkan fakultas lainnya. Dana cadangan ini dapat dioptimalkan untuk melakukan berbagai strategi pengembangan yang bisa dilakukan untuk kategori 'Question Mark' ini yaitu: penetrasi pasar; pengembangan pasar; pengembangan produk atau jika perlu melakukan divestasi/harvesting (David,
2009). Fakultas-fakultas yang berada pada kategori ini harus meningkatkan fasilitasnya, karena lemahnya pendanaan yang diperoleh dari pendapatan, sebagaimana dinyatakan oleh Aprilia \& Susilo (2016) merupakan kendala bagi ketersediaan sarana dan prasarana yang memuaskan (Tobari, 2015). Karena tanpa fasilitas yang memuaskan maka sulit bagi fakultas untuk mendapatkan keunggulan yang bisa memuaskan para penggunanya (Sukandi, 2010).

\section{SIMPULAN}

Daya saing merupakan alat untuk dapat memenangkan persaingan. Perguruan tinggi itu sendiri telah memasuki era industri pendidikan tinggi yang tidak saja memiliki misi sosial namun bahkan sudah masuk pada segi komersil/bisnis, khususnya bagi perguruan tinggi swasta. Sehingga dengan demikian, pemetaaan daya saing, baik yang sifatnya internal maupun eksternal, perlu untuk secara konsisten dan berkelanjutan untuk dilakukan agar pengelola perguruan tinggi mengetahui apa yang ingin dicapainya dengan cara memosisikan kondisi saat ini agar dapat melakukan langkah-langkah strategis untuk bisa mencapai tujuan yang ingin dicapai. Penelitian ini dilakukan untuk memetakan daya saing internal antar fakultas yang ada di lingkungan Universitas Lancang Kuning dengan menggunakan pendekatan performa finansial masing-masing fakultas tersebut.

Hasil penelitian menyimpulkan bahwa tiga fakultas yang paling tinggi daya saingnya adalah Fakultas Ilmu Komputer, Fakultas Ekonomi dan Fakultas Hukum. Ketiga fakultas ini terbukti memiliki pangsa pasar relatif yang tinggi dan memiliki tingkat pertumbuhan pendapatan yang tinggi. Dalam hal pembentukan dana cadangan, Fakultas Hukum dan Fakultas Ilmu Budaya merupakan dua fakultas yang paling tinggi dana cadangannya. Sebaliknya, Fakultas Ekonomi dan Fakultas Ilmu Komputer, meskipun kemampuan menggenerate pendapatannya sangat tinggi, namun kemampuan membentuk dana 
cadangannya sangat rendah. Bahkan secara khusus pada Fakultas Ekonomi, pengelolaan pengeluarannya lebih tinggi dari laju pertambahan pendapatannya. Sementara Fakultas Ilmu Komputer cukup berhasil menjaga rasio pertumbuhan pengeluarannya dibawah laju peningkatan pendapatan.

Temuan lain dari penelitian ini adalah bahwa Fakultas Pertanian secara konsisten mampu menjaga seluruh rasio performa keuangan tetap positif, baik dari aspek pertumbuhan jumlah pendapatan, jumlah pengeluaran maupun pembentukan dana cadangan. FAPERTA mampu menjaga pertumbuhan pengeluarannya dibawah laju pertumbuhan pendapatannya, sehingga meskipun tidak besar, namun performanya tetap menunjukkan hasil yang surplus. Artinya pengelolaan pengeluaran relatif dilakukan secara efisien.

\section{DAFTAR RUJUKAN}

Anggrianto, M., C.I. Parwati dan Sidharta. (2013). Penerapan Metode SWOT dan BCG Guna Menentukan Strategi Penjualan. Jurnal REKAVASI, 1(1), 52-61

Aprilia, N. dan M.J. Susilo. (2016). Evaluasi Pelaksanaan Program Pendidikan Guru MIPA Unggulan di Prodi Pendidikan Biologi Universitas Ahmad Dahlan Yogyakarta. Prosiding Symbion (Symposium on Biologi Education), Prodi Pendidikan Biologi, FKIP, Universitas Ahmad Dahlan, 27 Agustus 2016, 341-354

Assauri, Sofjan. (2012). Strategic Marketing: Sustaining Lifetime Customer Value. Jakarta: Rajagrafindo Persada

Breznik, L., dan M. Lahovnik. (2016). Dynamic Capabilities and Competitive Advantage: Findings From Case Studies. Management, 21, 167-185
David, Fred R. (2009). Strategic Management. Jakarta: Salemba Empat

Davis, P.M. dan W.H. Walters. (2011). The Impact of Free Access to the Scientific Literature: A Review of Recent Research. J. Med. Libr. Assoc. 99(3), 208-217

Hayati, N. dan D. Satori. (2015). Daya Saing Sekolah Tinggi Ilmu Ekonomi. Jurnal Administrasi Pendidikan, XXII (1), 152-169

Hermawan, S. dan H. Widodo. (2008). Analisis Model Laporan Keuangan Dalam Upaya Meningkatkan Akuntabilitas Publik Pengelolaan Keuangan Perguruan Tinggi Swasta di Kabupaten Sidoarjo. Jurnal BETA, 7(1), 2-17

Rakhmat, J. (2009). Metode Penelitian Komunikasi Dilengkapi Contoh Analisis Statistik. Bandung: Remaja Rosdakarya

Rosalin, Elin. (2010). Membangun Competitive Advantage Perguruan Tinggi Dalam Menghadapi Tantangan dan Perubahan Abad 21. Jurnal Manajemen Pendidikan, 02/Th.VI. 9-26

Sarjono, H. dan E.A. Kuncoro. (2013). Analisis Matriks Boston Consulting Group (BCG) Untuk Memenangkan Strategi Organisasi (Studi Kasus Perguruan Tinggi di Kopertis Wilayah III - DKI Jakarta). Binus Business Review, 4(1), 414-422

Suci, Afred. (2017). Internasionalisasi Mutu Perguruan Tinggi. Artikel di http://www.berseripos.co.id/read/b erita-8064/sistem-akreditasiperguruan-tinggi-adilkah.php 
Sukandi, Pipin. (2010). Hubungan Antara Fasilitas Kampus Terhadap Kepuasan Mahasiswa Dalam Menghadapi Daya Saing Pendidikan (Studi Kasus: Mahasiswa Fakultas Bisnis dan Manajemen Universitas Widyatama). The $4^{\text {th }}$ PPM National Conference on Management Research, Jakarta 25 November 2010

Sukrisno, Heni. (2011). Akuntabilitas Mutu Pelayanan Perguruan Tinggi. Jurnal Pendidikan dan Pembelajaran, IX(1), 81-89

Suroto, B., Nofrizal dan Fatkhurahman. (2016). Identifikasi Jiwa Kewirausahaan Mahasiswa (Studi Kasus Pelaksanaan Program Unggulan Kewirausahaan). Jurnal Benefita, 1(3), 154-162

Tobari. (2015). Strategi Perguruan Tinggi Swasta Menghadapi Persaingan. Jurnal Media Wahana Ekonomika, 12(3), 61-68

Wang, Hui-Ling. (2014). Theories for Competitive Advantage. A Publication of the THEORI Research Group, University of Wollongong, Australia. http://eurekaconnection.files.wordpr ess.com 